\title{
The application of a Humanistic approach to health care and education
}

\author{
Diesmy Humaira Biruny ${ }^{1, *}$ and Izdiharmada Salsabila ${ }^{1}$ \\ ${ }^{1}$ University of Muhammadiyah Malang, Indonesia \\ *Corresponding author: diesmyhumaira@webmail.umm.ac.id
}

KEYWORDS

Humanistic

Mntal health care

Education

Systematic literature review

\begin{abstract}
The humanistic approach tries to see human life as humans themselves see their life. Humanists are more likely to hold an optimistic perspective on human nature. In the development of his theory, humanistic psychology is very concerned about the human dimension in the relationship with the environment humanely by focusing on individual freedom to express opinions and make choices, values, personal responsibility, autonomy, purpose, and meaning. This study uses a systematic literature review method by identifying, assessing, and interpreting all findings on a research topic, to answer research questions. The humanistic approach emphasizes the importance of individual life by not seeing the negative side of the individual and helps individuals increase their potential even in crises so that individuals can actualize themselves.
\end{abstract}

(c) The Author(s) 2021.

\section{INTRODUCTION}

The humanistic approach is one approach or the flow in psychology that emphasizes free will, the growth will be private, the excitement, the ability to recover after experiencing unhappiness, and success in the realization of human potential as well as the learning process will not be successful if there is no motivation and supportive environment. Humanistic goals are to help humans express themselves creatively and realize their full potential. As Crain explained that the humanistic approach emphasizes the main good of humans and their potential, creativity, health, hope, meaning, connection, purpose, and the ability to achieve self-actualization, or for individuals to reach their full potential [1].

Humanistic emphasizes the primary goodness of humans and human potential [1]. Humanistic focus on subjective human experiences and rejection of determinism in favor of human choice [1]. Humanistic focus on subjective human experiences and rejection of determinism in favor of human choice [2]. The humanistic theory discovered by Maslow focuses on how the whole human being can achieve self-actualization according to the stage of age development. Humanists focus on the ability possessed by humans to think consciously and rationally in controlling their biological desires and in achieving their maximum potential. Free choice for self-determination, freedom, and responsibility, anxiety as a basic element, the search for unique meaning in a meaningless world, being alone and in contact with others, finitude and death, and a tendency to selfactualize.

In the humanistic approach, several cases can be discussed and raised in research including self-actualization such as research conducted by Erdogan \&Tugba on $23 \mathrm{stu}-$ dents in Turkey, which explained that the level of percep- tions of gifted students was higher than students who were not gifted in terms of self-actualization, social relationships, creativity, critical thinking, and emotional integrity. Besides, it is also known that students who attend preschool education have a higher level of self-actualization [3]. Neither did Ali, who explained that pleasure, strength, freedom, and love as well as needs that are included among the basic needs of prospective teachers have a significant influence on self-actualization. However, only survival necessity has no significant effect on teacher candidate selfactualization [4].

Another theme that can be discussed is the fully functioning person. Bazzano explains that meditation helps us appreciate the imperfections of life as a gift [5]. This could mean that this life is already the life of the Buddha, already the life of a fully functioning person. Recent research found on perfectionism, Fuschia et al., Suggested that a tendency for perfectionism to be associated with poorer physical health for individuals living with chronic health conditions proves that an atmosphere of mutual respect for freedom of opinion expresses ideas impacts on health conditions [6]. The exploration of nonlinear relationships provides an opportunity to not only see the strength of the associations between the variables of interest but also to see the depth and quality of the change as it occurs. Emphasizing the importance of meaning in individual life opposes other approaches to provide a statement about the meaning of life, especially in its application to health care and education as well as the learning process. The results provided by current humanistic theory reach an understanding of the meaning in the human experience that is understood. The purpose of this paper is to determine how the application of a humanistic approach to health care and education. 


\section{THE APPLICATION OF THE HUMANISTIC APPROACH}

Among the humanistic theories, the ideas of Abraham Maslow and Carl Rogers are the most famous. Abraham Maslow is known as a pioneer of humanistic psychology by trying to understand behavior in terms of the needs that motivate an individual. Recognition that not all needs are equal prompted him to formulate a hierarchy of needs, which ranged from basic safety needs to creative desires represented in self-actualization [2]. Maslow's theory is based on the idea that experience is a major phenomenon in the study of learning and human behavior. He emphasized choice, creativity, values, self-realization, all distinctive human qualities, and believed that meaning and subjectivity were more important than objectivity.

Self-actualization can be seen as the highest need for a hierarchy of needs but can be seen as the final goal, the ideal goal of human life. This concept of life purpose as a motivator is similar to Jung's self-arsenal, Adler's selfcreative power or Horney's self- realization. According to Maslow, the goal to achieve actualization themselves are naturally carried since birth. By genetically, humans have positive potential grounds. Humans have the basic potential of a healthy developmental pathway to achieve self - actualization [7].

\subsection{Humanistic applications in health care}

Humanistic theory in the field of health care is also still frequently carried out in recent research as did Jackson et al., On Maslow's hierarchy of needs, providing the framework and spark needed to improve care for delirium patients with a patient-centered emphasis on physical and psychological complaints. experienced [8]. In nursing, humanism is an attitude and approach that treats patients as humans who have needs more than just a bed number or as a certain disease. nurses who use a humanistic approach in practice take into account everything they know about the patient including thoughts, feelings, values, experiences, preferences, and body language. Watson believes that humanistic care attaches to the fundamental belief in internal forces in the care process to produce growth and change in individuals, beliefs and expectations can facilitate [9].

Rogers developed a model that focuses on the relationship between what we feel as ourselves (the self) and what we feel we should be (the ideal self). When both are experienced as the same thing, the individual is congruent or fully functioning. When there is a gap between the self and the ideal self, the person will experience this as a mismatch / incongruence. Being congruent depends on meeting the people who provide the conditions for growth : empathy, openness and unconditional positive regard. The inconsistency of results from other people who set the conditions for worth is then expressed through conditional positive regard [2]. As in the Kae-Hwa \&Gyeong study which resulted in the conclusion that a humanistic end-of-life care course was effective in reducing negative attitudes towards death and improving the communication skills of Korean nursing students.

\subsection{Humanistic applications in education}

Humanistic psychology explores the potential that an individual has to develop and helps direct the development process, especially social, interpersonal and emotional potential. This theory has the aim to humanize humans. Learning in the theory of humanism is successful if learners can understand the environment and of itself (self-actualization). Teachers in humanism theory help students to understand deeply about themselves so that students can develop existing abilities in themselves as well as create learning that can increase their ability to create, feel and fantasize [11]. The teacher becomes a facilitator for students, provides motivation, awareness of the meaning of learning in student life. Teachers facilitate learning experiences for students and assist students to achieve learning objectives.

The theory more direct and lead the students to think inductively, increase experience, and require active student involvement in the learning process [12]. Idris and $\mathrm{Za}$ explained that education aims to mature humans based on humanist values, to maintain human existence, and dignity [13]. Students will grow to become someone who loves fellow humans, loves nature and increases their devotion to God

At humanistic education there are several very basic points, namely: (a) Students must have a substantial handle on the direction of education they do, both in terms of choosing lessons and on how to learn them; (b) There are elements of taste and creativity, which must be considered and need to be developed in the teaching and learning process; (c) Educators must create a classroom environment that can ensure the teaching and learning process, because one of the characteristics of a humanistic classroom is a safe and comfortable classroom environment, so that students feel confident that they can learn and can do positive things; (d) Humanistic education is expected to help students to be able to manifest themselves according to their basic potential, so that humanistic goals can be achieved, namely humans who are able to actualize themselves in the middle of community life according to their potential [14].

Motivation and emotional experiences are very influential in learning. If there is no motivation to learn, there will be assimilation of new knowledge into the existing cognitive structures. Rogers argues that there are five important things in the humanistic learning process [11]: (1) the desire to learn, (2) meaningful learning, (3) learning without punishment, (4) learning on one's own initiative, and (5) learning and change. Humanistic theory in learning is more directing students to increase their potential which requires the involvement of students in the learning process and the teacher as their mediator [12].

\section{RESEARCH METHOD}

Using a systematic literature review, which is a research method to identify, evaluate, and interpret all relevant research results related to certain research questions, certain topics, or phenomena of concern [15]. There are three stages in this method: (1) Planning research question is the initial and basic part of its operation, used to guide the process of searching and extracting literature related to the application of a humanistic approach to health care and education. Data analysis and synthesis, as a result of systematic literature review, is the answer to the research question that has been determined in advance; (2) The conducting stage is the stage that contains the implementation of systematic literature review, which should be in accordance with the systematic literature review protocol, namely the determination of the search for literature (search strings), understanding synonyms and alternative word substitutes 
will determine the accuracy of the search for literature determining the source (digital library) from searching the literature, selecting the appropriate literature, data extraction, to synthesizing various things that have been found from the existing literature (synthesis of evidence); (3) Reporting is the stage of writing the results of systematic literature review in written form.

\section{RESULTS AND DISCUSSION}

Everyone has fear, such as fear of trying or developing, fear of taking chances, fear of jeopardizing what they already have and so on. But it encourages him to progress towards perfection, self-confidence and at that moment he can accept himself. The humanistic approach is characterized by two basic assumptions that distinguish its methodology and theory from other approaches, namely a focus on subjective experiences and a rejection of determinism that supports individual choice. A unique humanistic approach in emphasizing questions such as the role of meaning and spirituality in human life [2].

This humanistic approach embraces everyone and does not see what humans are like and accepts humans unconditionally in order to develop the potential that exists in humans that appear [1]. Early humanistic approaches focus on humanistic perspectives in health and education. In healthcare explained that people who experience pain then attempts in the quality of life will increase because of the approach of the individual to God. Excellence in carrying out health care on a humanistic basis can be applied to patients even though the patient is vulnerable and not interactive [16].

Humanistic psychology's attention is mainly focused on the problem of how individuals are influenced and guided by personal purposes which they connect to their own experiences, especially in treating psychological health and physical health, and education [17]. Humane humans are not selfish humans, but those who are willing to sacrifice for others.

Excellence in carrying out health care on a humanistic basis can be applied to patients even though the patient is vulnerable and not interactive. The nurse who uses the humanistic approach in practice takes into account everything she knows about the patient including thoughts, feelings, values, experiences, likes, behavior and body language. As health care with a humanistic approach is meant not from a professional point of view, but as a response from fellow humans who need each other and are full of acceptance [18].

Rogers developed a model that focuses on the relationship between what we feel as ourselves (the self) and what we feel we should be (the ideal self). When both are experienced as the same thing, the individual is congruent or fully functioning. When there is a gap between the self and the ideal self, the person will experience this as a mismatch. Being congruent depends on meeting the people who provide the conditions for growth : empathy, openness and unconditional positive regard. The inconsistency of the results from other people determining the conditions for worth , expressed through conditional positive regard [2]. The humanistic approach always tries to accept unconditional individuals (unconditionally positive regards) in order to develop individual potential [1].
In education, the humanistic approach helps to increase the potential for success, identifying barriers to learning [19]. The problems facing the world of education in Indonesia today are: (a) The teaching and learning process that takes place mechanically; (b) The teaching and learning process runs in a monologue and there is a unidirectional relationship so that students are passive towards the material given; (c) The teaching and learning process emphasizes one aspect, namely the cognitive aspect that makes students not have the opportunity to develop the potential and other human dimensions, namely, the effective, social and psycho-motor aspects; (d) The content of the curriculum is very heavy and dense and is not adapted to the needs of students, so that students are negative, pessimistic, and do not have motivation for the material provided [14]. Competency-based curriculum planning is a positive rarity because it is based on the abilities and competencies of students; (5) Educators no longer act as central figures but rather become motivators, dynamics and facilitators for students. And what educators need to realize is that they are not the only source of knowledge; (6) Twoway communication and openness have an important role in the teaching and learning process [14].

The essence of humanistic counseling emphasizes a philosophical reflection on what it means to be human. Balkin and Schmit explained that the humanistic approach in clinical counseling explores the relationship which provides an opportunity not only to see the strength of the association between variables but also to see the depth and quality of changes in counseling, so that counseling can understand individuals who are experiencing crisis in depth [20].Counseling with a humanistic approach focuses on the human condition. This approach is primarily an attitude that emphasizes an understanding of humans. Humanistic views humans as creatures who have authority over their lives. Humans are free to be what and who they want. Humans are living beings who determine for themselves what they want to do and what they don't want to do, because humans are creatures that are responsible for everything they do. A counselor who uses a humanistic approach helps deeper when identifying conflicts to help remove client barriers with the aim of improving the client's mental health [21].

\section{CONCLUSION}

Humanistic views humans as creatures who have authority over their own lives. Humans are free to be what and who they want. Humans are living beings who determine for themselves what they want to do and what they don't want to do, because humans are creatures that are responsible for everything they do. Humanistic can be used in education and health. This humanistic approach explains how to humanize humans without seeing the negative side of humans themselves. This approach also states that every human being is valuable and that they all have the right to enjoy their life. Humans also have potential that cannot be raised due to the possibility of a lack of self-confidence that is owned by humans themselves, educators will become facilitators and not only provide material but also help in developing and bringing out that potential. 


\section{REFERENCES}

[1] W. Crain, Theories of Development: Concepts and Applications, sixth ed, New Jersey: Pearson, Upper Saddle River, 2014.

[2] W. \&. H. M. Glassman, Approaches to Psychology, New York: McGraw-Hill Education, 2009.

[3] D. G. Y. T. Erdogan, "Perceptions Of Gifted And Non-Gifted Students Related To Their Levels Of Self Actualization.," Eurasian Journal of Educational Research , no. 68, pp. 203-220, 2017.

[4] A. Ali, "Basic needs as a predictors of prospective teachers' self-actualization.," Universal Journal of Educational Research, vol. 5, no. 6, pp. 1045-1050, 2017.

[5] M. Bazzano, "The Buddha as a fully functioning person: toward a person-centered perspective on mindfulness.," Person-Centered E Experiential Psychotherapies, vol. 10, no. 2, p. 116-128, 2011.

[6] Fuschia M. Sirois, "Trying to be perfect in an imperfect world: A person-centred test of perfectionism and health in fibromyalgia patients versus healthy controls," Personality and Individual Differences, vol. 137, pp. 2732, 2019.

[7] Alwisol, Psikologi Kepribadian, Malang: UMM Press, 2018.

[8] Jackson, "Improving patient carae through the prism of psychology: Application of Maslow's Hierarchy to sedation, delirium, and early mobility in the intensive care unit," Critical Care, vol. 26, 2014.

[9] J. Watson, "Watson's Theory of human caring and subjective living experience: Charative, factor/charitas, proceccess as a disiplinary. Guide to the Profesional Nursing Practice.," Texto Contexto and Ferm, Florianopolis, vol. 16, no. 1, pp. 129-135, 2007.

[10] Kae-HwaJo and Gyeong-JuAn, "Effect of end-of-life care education using humanistic approach in Korea," Collegian, vol. 22, pp. 91-97, 2015.

[11] M. A. Setiawan, Belajar dan pembelajaran, Jakarta: Uwais Inspirasi Indonesia, 2002.

[12] H. Darmadi, Pengembangan Model dan Metode Pembelajaran dalam Dinamika Belajar Siswa, Yogyakarta: DeePublish, 2017.

[13] S. Idris and T. Za, "Realitas konsep pendidikan humanisme dalam konteks pendidikan Islam," Jurnal Edukasi Jurnal Bimbingan Konseling, vol. 3, no. 1, pp. 96-113, 2011.

[14] Haryu., "Aplikasi psikologi humanistik dalam dunia pendidikan di indonesia (Konsep arthur w. Combs tentang pengembangan potensi anak).," Tadrîs, vol. 1, no. 1, pp. 75-90, 2016.

[15] B. Kitchenham and S. Charters, "Guidelines for performing Systematic Literature Reviews in Software Engineering.," EBSE Technical Report Version 2.3, , 2007.

[16] K. L. McCamant, "Humanistic nursing, interpersonal relations theory, and the empathy-altruism hypothesis," Journal Nursing Scence Quarterly, vol. 19, no. 4, pp. 334338, 2006.

[17] V. F. Sangganjanavanich and R. S. Balkin, "Burnout and job satisfaction among counselor educators," The Journal of Humanistic Counseling, vol. 52, no. 1, pp. 67-79, 2013.

[18] K. McCamant, "Humanistic nursing, interpersonal relations theory, and the empathy-altruism hypothesis," Journal Nursing Science Quarterly, vol. 19, no. 4, pp. 334-338, 2006.
[19] M. M. Ohlsen, "Humanistic teaching," The Journal of Humanistic Education and development, vol. 35, no. 3, 2011.

[20] R. S. Balkin and E. L. Schmith, "A humanistic framework using nonlinear analysis to evaluat the working alliance and coping for adolesence in crisis," The Journal of Humanistic Counseling, vol. 57, no. 1, pp. 2-13, 2018.

[21] R. S. Balkin, M. Perepicka, S. M. Sowell and P. B. Gnilka, "The Forgiveness Reconciliation Model: An Empirically Supported Process for Humanistic Counseling.," The Journal of Humanistic Counseling, , vol. 55, no. 1, pp. 55-65, 2016. 